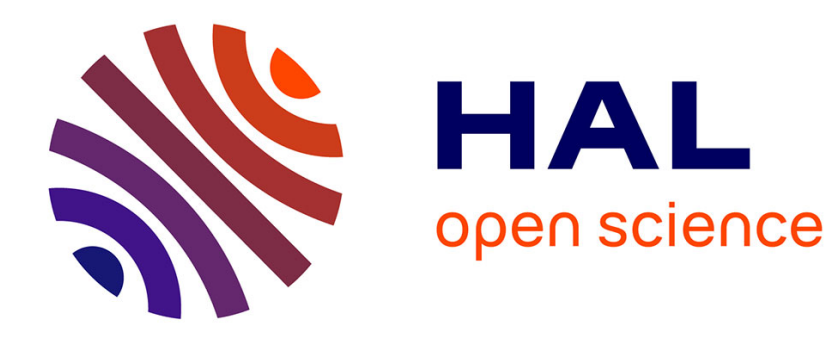

\title{
Laughter, Social Norms, and Ethics in Cicero's Works
} Charles Guérin

\section{To cite this version:}

Charles Guérin. Laughter, Social Norms, and Ethics in Cicero's Works. Destrée, Pierre; Trivigno, Franco. Laughter, Humor, and Comedy in Ancient Philosophy, Oxford University Press, pp.122-144, 2019. hal-02357084

\section{HAL Id: hal-02357084 https://hal.science/hal-02357084}

Submitted on 29 Jan 2021

HAL is a multi-disciplinary open access archive for the deposit and dissemination of scientific research documents, whether they are published or not. The documents may come from teaching and research institutions in France or abroad, or from public or private research centers.
L'archive ouverte pluridisciplinaire HAL, est destinée au dépôt et à la diffusion de documents scientifiques de niveau recherche, publiés ou non, émanant des établissements d'enseignement et de recherche français ou étrangers, des laboratoires publics ou privés. 


\title{
Laughter, Social Norms, and Ethics in Cicero's Works
}

\author{
Charles Guérin
}

It was customary for members of the Roman elite to maintain an active correspondence with their familiares when away from Rome. The correspondents would often lament the distance, the lack of an actual face-to-face discussion, or the scarcity of the letters they received. But Cicero would sometimes add another complaint to these: what he also missed was the lack of a good laugh with his friends.' Jokes and witty remarks were a central feature of elite sociability, but also a prominent_-though controversial-aspect of Cicero's public persona, who considered himself a wit and practiced the art of joking (risum movere) in all possible forms.

But Cicero was not a mere jester. He also contributed to the ancient reflection on laughter and is our most important Latin source on the issue. As a philosopher and a rhetorician, he tried to offer a comprehensive analysis of laughter and found himself in a peculiar position. First, he had to take into account the many debates that had flourished on the topic since the 4th century BCE in the Greek world. He also had to take a pragmatic stance: laughter was nothing abstract or theoretical for him, but something he dealt with on a daily basis, either in his various social encounters or as part of his forensic and political activity. And since one of his aims, from 55 BCE onward, was to Romanize the teachings of the Greeks and to ground their literature and philosophy in a Roman cultural and social context, he had to present his readers with a properly Roman understanding of laughter. As a "social practice with its own codes, rituals, actors and theatre" (Le Goff 1989: 40), laughter always has a vernacular ring, and Cicero needed to pinpoint what could make laughter specifically Roman. ${ }^{2}$

For Cicero, laughter is one of the most crucial aspects of a civilized relationship: it creates warmth, eases the tensions that arise in human encounters, and strengthens the bonds of friendship. However, he also embraces the fact that laughter is commonly used as a weapon in the Roman public sphere, as scholarship on ancient laughter has pointed out. ${ }^{3}$ When used aggressively, jokes and puns offer an efficient way to call an opponent's behavior and morality into question, and thus weaken his social and civic standing. Those two aspects might seem incompatible at first, and one might conclude that, for Cicero, laughter simply had both a public (or aggressive) and a private (or friendly) side. As a matter of fact, Cicero analyzes laughter from two different and complementary angles, one mostly rhetorical in his dialogue

\footnotetext{
${ }^{1}$ See, for example, Att. 1.18.1; Fam. 1.10 (L. Valerius); 2.13.3 (Caelius); 15.19.1 (Cassius). Cf. Hutchinson 1998: $172-79$.

${ }^{2}$ Cf. Fam. 9.15.2, where Cicero complains that foreign influences are ruining traditional Roman jest.

${ }^{3}$ See Richlin 1983; Corbeill 1996; Guérin 2011: 154-69; and Beard 2014: 105-8 (for a criticism of this approach).
} 
On the Orator (De oratore, 55 BCE) and his treatise The Orator (Orator, 46 BCE), and one ethical in his treatise On Duties (De officiis, 44 BCE). It could be tempting to restrict Cicero's properly philosophical analysis of laughter to De officiis, and to reject the relevant passages of De oratore as a kind of manual explaining how to use laughter in a forensic or political setting, and how to abide by the social norms regulating the proper use of wit in oratory. De officiis, then, would deal with the friendly side of laughter from an ethical point of view, and $D e$ oratore with the violent one, in a pragmatic approach. But De oratore and De officiis show no sign of such a division, and the scope of De oratore encompasses at times both the forensic and the private sides of laughter. ${ }^{4}$

Laughter is obviously a unified phenomenon for Cicero: friendly jokes and aggressive witticisms belong to a continuum. ${ }^{5}$ More generally, it would be a mistake to isolate Cicero's philosophical thought (on laughter, or on anything else) from his political and literary activity, or even from his struggle for recognition and social climbing. ${ }^{6}$ A correct reading of Cicero's writings on laughter will be possible only if we accept the entanglement of, first, the social and rhetorical agenda driving him, and, second, the philosophical commitments that shape his understanding of ethics. This essay tries to offer such an approach by linking Cicero's ethical concerns on the subject, and his pragmatic precepts regarding the use of jokes. Whether friendly or violent, laughter is seen by Cicero as a mode of communication regulated by a set of social norms, which echo a very Roman understanding of what a proper public behavior should be. But since social norms are at the core of the self as it is conceived by Cicero in $D e$ officiis, laughter can also be analyzed in relation to the agent's individual character taken as an ethical touchstone. Laughter thus is tackled by Cicero with three different uses and contexts in mind: the enhancing of human relationships, the enforcing of the norms shared by the community, and the maintaining of the ethical agent's individual coherence.

\section{Jokes, Friendliness, and Sociability}

In Cicero's letters, friendliness (comitas) is one of the chief qualities expected from a correspondent. This friendliness aims at strengthening a relationship and creating a sense of closeness (familiaritas) when the circumstances do not allow the face-to-face meetings that form the core of social life for the Roman elite. ${ }^{7}$ It appears through the evocation of shared references, through a careful choice of words, and, above all, through a warmth that usually involves joking and laughing accordingly. A friendly exchange (sermo familiaris) needs to

\footnotetext{
${ }^{4}$ See De orat. II.271 on irony, which Cicero considers "appropriate both for public speaking and for urbane conversation." Unless otherwise specified, translations from Greek and Latin texts are taken (sometimes with modifications) from Atkins and Griffin 1991 (Off.); Schackleton Bailey 1999 (Cicero's correspondence); May and Wisse 2001 (De orat.); Kennedy 2007 (Rhet.); Bartlett and Collins 2011 (EN).

${ }^{5}$ Lévy 1993: 407-8.

${ }^{6}$ Dugan 2005.

${ }^{7}$ See Fam. 15.14.3-4, White 2010: 17-21; Bernard 2013: 80-81.
} 
include jokes and puns, ${ }^{8}$ and even implies the use of a particular epistolary genre. In the typology Cicero builds up for C. Curio's sake in 53 BCE (Fam. 2.4.1), he has four distinct categories of letters in mind. The first one is informative, the second deals with private affairs, the third one is familiar and funny (genus familiare et jocosum) and is directly opposed to the last one, which deals with serious matters in a severe fashion (genus severum et grave). ${ }^{9}$ Among Cicero's letters, very few fully belong to the "familiar and funny" type, but those that do always have the same purpose: getting a relationship back on track by easing the tension after a misunderstanding or a strong disagreement..$^{10}$ The epistolary genres are usually mixed, and letters alternate jokes and puns with more serious matters in order to keep a potentially tense exchange as relaxed as possible." At any rate, raising laughter seems to be a legitimate and useful aspect of epistolary practices in Cicero's time. In that regard, letters are similar to an actual, face-to-face discussion (sermo).

The ability to discuss and share one's views is a defining feature of human sociability for Cicero, as his De officiis, written in 44 BCE, clearly shows. Based on the (now lost) treatise

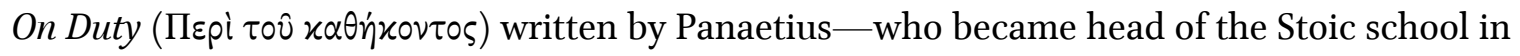
Athens in 129 BCE after living in Rome-, the first two books of De officiis remain very close, as far as we can tell, to the Panaetian understanding of duties in a civic context. ${ }^{12}$ If one can find a properly Ciceronian-and Academic - touch to some developments, Cicero nevertheless adheres entirely to the social and civic philosophy he has found in Panaetius, and turns it into an ethic that is largely congruent with the expectations of the Roman elite. Putting aside the ideal sage, Cicero deals in a very pragmatic way with the Stoic theme of human fellowship and with the obligations this fellowship entails in everyday life. ${ }^{13}$

De officiis holds reason and speech (ratio and oratio) to be the very bond uniting all human beings into "a kind of natural fellowship" (quaedam naturalis societas). Human beings, as opposed to beasts, are meant to communicate, teach, learn, debate, and persuade one another: their very humanity depends on their ability to forfeit violence and show kindness (benignitas) through their deeds and words (Off. I.5O). ${ }^{14}$ The stress Cicero puts on the importance of community and public speech goes far beyond the usual praise of eloquence derived from the sophistic tradition. ${ }^{15}$ Already in his De inventione (c. 86 BCE), Cicero depicted

\footnotetext{
${ }^{8}$ Bernard 2013: 230-31.

${ }^{9}$ On these categories, see also Fam. 4.13.1, 7.5.4-5, Att. 9.4.1.

${ }^{10}$ See, for example, Quint frat. 2.9 and Fam. 7.8 (Trebatius), and the commentary by Hutchinson 1998: 179-91.

${ }^{11}$ Bernard 2013: 226-46.

${ }^{12}$ See Off. 3.20 on the doctrinal freedom conveyed by the Academy. On the relationship between Stoic and Academic doctrines in Off., see Lévy 1989; Lévy 1992: 521-33; Prost 2001. On Cicero's use of Panaetius, see Dyck 1996: 1-29.

${ }^{13}$ Reydams-Schils 2005, esp. chap. 2; Kennerly 2010: 122-24, 128-31.

${ }^{14}$ On ratio and oratio as defining features of human societas and civitas, cf. Inv. 1.2; Rep. I.1; Laws I.23; Off. I.12; Schofield 1999: 67-72; Lévy 1995; Connolly, 2007: 166-69.

${ }^{15}$ See, for example, Isoc. Ad Nic. 6.
} 
the development of civilization as a victory over brutality and cruelty, thanks to the use of public discourse regulated by reason. ${ }^{16}$ The core idea illustrated by this myth-clearly dependent on the teachings of Philo of Larissa, ${ }^{17}$ the last head of the Academy and teacher of Cicero-reemerges in De officiis but is now linked to the Stoic concern for human fellowship and communication. Oratory (oratio) helped unite human beings in De inventione, and now gives way to discussion (sermo) as a means of maintaining human interactions in their best possible state.

Sermo, as oratio, is a manifestation of reason and is viewed as the very opposite of violence. Moreover, sermo is also opposed to the tension or competition (contentio) that defines oratory. Sermo, therefore, is chiefly characterized by this absence of tension. It should be "gentle and without a trace of harshness (lenis minimeque pertinax); it should also be full of charm (lepos)" (Off. I.132), ${ }^{18}$ and one ought to engage in a discussion only for the pleasure it provides, not to dominate the exchange in any way or to pursue any agenda (Off. I.134). Thus, proper sermo is characteristic of the freeborn and well-educated man, and the absence of aggressiveness goes along with the potential charming effect one's words can have on others. In fact, the word lepos fully belongs to the realm of humor, and is also used by Cicero to describe the mix of attractiveness and wit that one encounters among the Socratics. ${ }^{19}$

Cicero views wit and laughter as essential components of a well-balanced and pleasant exchange. Although, as he points out, "we have not been created by nature to seem as if we were made for jesting and play, but rather for earnestness," De officiis acknowledges the necessity of joking and relaxing "when we have given enough time to weighty and serious matters" (Off. I.103). ${ }^{20}$ We find here again the ideal of equilibrium that presides over the exchange of letters. One cannot conceive a mode of communication that excludes laughter entirely, and laughter must give an exchange a friendly touch-or at least keep it as friendly as possible ${ }^{21}$-rather than damage it. Joking freely (libere jocari) is the essence of a successful discussion. ${ }^{22}$

Those remarks are perfectly in line with the Greek tradition. Plato, in his Laws, draws a sharp distinction between morally good and morally bad humor, and uses the presence or absence of aggressiveness (thumos) as a criterion. Laughter shall be acceptable only if it is free of any thumos, if it is not used to obtain an advantage on others and if it does not aim at

\footnotetext{
${ }^{16}$ Inv. 1.2.

${ }^{17}$ Lévy 1992: 98-10o; Lévy 1995: 159-63.

${ }^{18}$ Cf. Lévy 1993: 403.

${ }^{19}$ Krostenko 2001: 97 and 204; Guérin 2009: 388-89.

${ }^{20}$ The remark is reminiscent of Aristotle, $E N 1127 \mathrm{~b} 33-1128 \mathrm{a} 2$, and typical of a Stoic approach (Halliwell 2008: 3027).

${ }^{21}$ Laughter adds a useful friendly touch when an exchange is becoming terse: see, for example, De orat. III.46, Fin. 5.86, Lucul. 148.

${ }^{22}$ See Att. 1.1.18, Fam. 16.21.3.
} 
hurting its object. ${ }^{23}$ We find a very concrete echo of this concern in one of Cicero's letters, where he regrets having joked at the expenses of Vettienus in too aggressive a manner

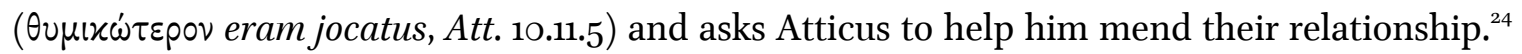
The joke was meant to tease Vettienus for having brusquely asked Cicero to pay what he owed in a business affair, and Cicero's move was obviously ill advised. Humor in a balanced relationship must have no other goal than laughter itself. Xenophon adopts the same stance in his Cyropaideia, where he condemns aggressive laughter, and praises friendly joking as something done without any other purpose than entertainment. ${ }^{25}$ Plutarch, commenting on Xenophon, will later stress the potential for harm that comes with laughter, and will advise caution when joking: aggressive jokes can hurt and humiliate their victims worse than an insult, and can ruin a conversation. ${ }^{26}$

By combining a traditional view of laughter as a social and friendly activity with the behavioral expectations of elite Romans, De officiis sets laughter within the framework of civic duties that must be observed in order to foster, or at least protect, human fellowship. While laughter, of course, is not a duty (officium) by itself, it helps fulfill several duties (officia) in day-to-day relationships. It also plays a role in the psychological approach that is prevalent in the treatise: in discussions, laughter is a most essential mark of comitas and familiaritas, and therefore a sign of the jester's good character, whom Cicero depicts as being pleasant (jucundus), cheerful (hilarus), entertaining (festivus), and witty (facetus). ${ }^{27}$

The relationship between laughter and character has been one of the most central issues in ancient discourses on the topic. Having a bodily origin, laughter carries a stigma that led the Pythagoreans to condemn it entirely - a condemnation that had a strong influence on many subsequent thinkers. ${ }^{28}$ Thus, besides his rejection of aggressive laughter, Plato condemns jokes and comic banter in general for their negative effects on one's character. In his Republic, in particular, excessive laughter is viewed as a threat to rationality, since it creates a "dangerous psychic turbulence," as S. Halliwell puts it, that debases the soul. ${ }^{29}$ A jester can ruin his character when he indulges too much in laughter..$^{30}$

\footnotetext{
${ }^{23}$ See in particular Laws 816e sq. On the different descriptions of this aggressiveness and the various emotions it implies (thumos, phthonos, orgè), see Chapter 1 ("Plato on Laughter and Moral Harm"), in this volume.

${ }^{24}$ Att. 10.5.3 and 10.11.5.

${ }^{25}$ Xen. Cyr. 2.2.12, 7.1.33.

${ }^{26}$ Plut. Conv. 2.1.4.

${ }^{27}$ On these characteristics, see Krostenko 2001: 202-32; Guérin 2011: 169-265.

${ }^{28}$ Halliwell 2008: 264-76.

${ }^{29}$ Rep. 388e-389b, 518a-b, 6o6c, and Halliwell 2008: 276-302 (quotation p. 30o).

${ }^{3 \circ}$ The topic of "the moral harm of laughter" (F. Trivigno) is extensively tackled in both the Philebus and the Republic: see Chapters 1 ("Plato on Laughter and Moral Harm") and 4 ("Divine and Human Laughter in Later Platonism”), §3.
} 
Cicero acknowledges the bodily origin of laughter, ${ }^{31}$ and repeatedly warns his readers against any excess in those matters. De officiis calls for moderation by condemning "the kind of jokes that is immoderate (profusum) and unrestrained (immodestum)" (Off. I.103). But the idea that one's character is debased by laughter itself is nowhere to be found in Cicero's analysis of day-to-day exchanges as long as it is self-restrained (as we will shortly see). Joking and jesting are viewed positively in Cicero's works, and are depicted as a required competence among the Roman upper class. Unsurprisingly, Cicero's first concern seems to be with the jester's image rather than with his soul.

In a letter to Volumnius, written in February 50 BCE, Cicero expresses his concerns about the lame jokes that were circulated in Rome under his name. He asks his friend to fight against these faulty attributions, and to protect his reputation as a wit. De oratore offers a set of rules regarding laughter and witticisms, and Cicero now explicitly asks Volumnius to apply them and decide for himself if he could possibly be the author of the jokes under consideration..$^{32}$ There is much at stake for his reputation, and Cicero does not want his own jokes to be mixed with other ones that reek of bad taste and low social standing. Jokes and witticisms were not only tools for everyday communication: they were also worth publicizing. Cicero did everything he could to circulate his own quips, and Quintilian mentions a threevolume anthology of Cicero's bona dicta, possibly edited by his freedman Tiro. ${ }^{33}$ We also know, thanks to the Letters, that Gaius Trebonius compiled a volume of Ciceronian witticisms in 46 BCE, and sent it as a gift to Cicero himself. The work of Trebonius is a token of affection and political support (amor), as it does much for enhancing Cicero's reputation. ${ }^{34}$

Joking thus turns out to be a very serious matter of public standing, apparently worth a lot of work and effort. But it is also a slippery slope, since poor jokes, as the ones Cicero decries in his letter, can badly stain a reputation. And of course, there is no general agreement on where the line should be drawn between a witticism and a poor joke, as Cicero notes in his letter to Trebonius:

You find wit in every saying of mine-another perhaps would not. (Fam. 15.21.2)

The literary tradition keeps a score that is not entirely positive for Cicero. Quintilian himself, for all his admiration, regrets that a large number of very poor dicta have been included in Tiro's compendium..$^{35}$ And various sources attest that Cicero's humor was not always well

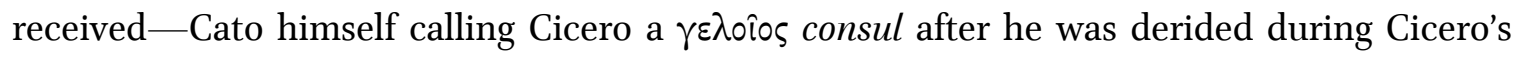
defense of Murena in 63 BCE. The quip was quite insulting, since geloios translates the Latin

\footnotetext{
${ }^{31}$ De orat. II.235.

${ }^{32}$ Fam. 7.32.2.

${ }^{33}$ Inst. 6.3.4-5.

${ }^{34}$ Fam. 15.21.2-3.

${ }^{35}$ Inst. 6.3.2, 5 .
} 
ridiculus, both "funny" and "ludicrous. ${ }^{36}$ Cicero deemed himself a wit, but others often found that he overplayed his own wittiness and fell into a degraded, almost vulgar, form of humor.

Aggressiveness is once again the central problem here. It is telling, however, that $D e$ officiis treats aggressiveness not as the cause of a bad joke, but as something that can be uncovered (indicare) through a discussion and can ruin a reputation:

One should take care above all that his speech does not reveal that there is some fault in his behavior; in general that happens particularly when someone speaks quite deliberately about people who are absent in an abusive or insulting manner in order to disparage them, whether he does so to raise a laugh or with severity. (Off. I.134)

Joking in an insulting way (contumeliose), therefore, not only threatens human societas, and directly hurts the victim. It also backfires on the jester himself and weakens his standing. This concern-preserving one's reputation while jesting - is clearly the most important one for Cicero. It supersedes the Platonic worry about character, and is seen as a necessary condition for familaritas, since one would not want to deal with someone who routinely debases himself by joking in an unacceptable manner. Cicero's analysis of laughter thus shifts from a perspective centered on the enhancement of human relationships to one centered on the shaping and preserving of the jester's persona. This second line of inquiry appears more clearly when one leaves the realms of sermo to enter those of contentio typical of public speech.

\section{Laughter, Community, and Control}

The sense of community fostered by the use of gentle joking during conversations, or in letter exchanges, takes a different shape when jokes are made in the competitive context of the Roman forensic or political arena. ${ }^{37}$ Here as well, laughter will prove useful for creating a bond among fellow citizens, but this bond will rest on a basis that seems to contradict all the rules we have encountered until now-namely, aggression and exclusion, as exemplified by $D e$ oratore.

\section{2.a. An Aggressive Approach to Laughter}

De oratore is a peculiar text in many ways. The characters of the dialogue, all of them great orators and jurists from the nineties BCE, discuss the nature of eloquence, its rules, its relationship to philosophy, and its use in a civic context. De oratore thus represents a lot more than a simple rhetorical treatise. It is both a reflection on public speech and its power, and a

\footnotetext{
${ }^{36}$ Plut. Cat. Min. 21, Plut. Comp. Dem. \& Cic. 1. See Beard 2014: 102-3. On the circumstances of this quip, see Craig 1986.

${ }^{37}$ Contentio goes beyond oratory, and can encompass philosophical controversies, where a harsh use of laughter can sometimes be found: see Lévy 1992: 172 sq.; Auvray-Assayas 1998.
} 
political manifesto asserting the importance of public debate and the role of knowledge in dealing with public issues, at a time when the usual political workings of the Republic were threatened and soon to yield to military power..$^{38}$ By defending eloquence as the only alternative to political violence, Cicero advocates a new understanding of rhetoric, grounded both in Roman tradition and Greek theories, which would reclaim as its own the teachings of philosophy and encompass much more than a simple set of abstract rules: the achievements of the great orators of the past, the needs of the Republic, the requirements of Roman mores, and actual oratorical practices.

As an essential feature of elite behavior, laughter becomes a valid object of inquiry for this new rhetorical approach, and De oratore sets about building the art to which Cicero refers in his letter to Volumnius. The claim that "it is fitting for the orator to stir up laughter" (De orat. II.236) might well signpost the whole project as a defense of Cicero's own behavior and use of jest. ${ }^{39}$ Nevertheless, the section on laughter (De orat. II.216-89, commonly referred to as de ridiculis) gives us invaluable insights into both Roman attitudes to laughter and Cicero's understanding of the phenomenon..$^{40}$

Through the speech delivered by the character of C. Julius Caesar Strabo Vopiscus (a renowned though controversial orator and wit of the nineties BCE), laughter is analyzed mainly as a political tool, a weapon to be used in order to convince, fight, and win the various battles of the public sphere. Cicero takes up an approach that Aristotle attributed to Gorgias, who considered laughter as a means to destroy the opponent's seriousness. ${ }^{41}$ It is along the same lines that Caesar Strabo expounds the usefulness of oratorical laughter:

It is indeed clearly fitting for the orator to stir up laughter [...] because laughter crushes an opponent, obstructs him, makes light of him, discourages him, defeats him. (De orat. II.236)

While he insists that his remarks are relevant both to private conversation and public speeches, Caesar Strabo neglects entirely the call for gentleness that is implicit in epistolary practices, and clearly stated in De officiis. With this comes a definition of the laughable that indeed leaves little room for gentleness and closeness:

The seat, the region, so to speak, of the laughable [...] lies in a certain dishonorableness (turpitudo) and ugliness (deformitas). (ibid.)

\footnotetext{
${ }^{38}$ For a general account of De oratore, see Fantham 2004.

${ }^{39}$ Dugan 2005: 104-46.

${ }^{40}$ For an overview of these passages, see Rabbie 1986; Fantham 2004: 186-208; Guérin 2011: 154-69; Beard 2014: 108-20.

${ }^{41}$ Rhet. 1419b3-7. According to Aristotle, Gorgias also advised to fight the opponent's jokes and laughter by seriousness — a view Cicero will not take up. See Celentano 1995: 167.
} 
Deformity, nonconformity, gross mistakes, and social degradation are the best sources of laughter. Such a definition entails a kind of humor mostly based on aggression, and meant to pinpoint someone's shortcomings.

In this context, laughter is not used the way it was in a friendly sermo. It now needs a victim to be laughed at, and supposes a gap between the jester and his audience on the one side, and the object of laughter on the other. If we turn to De oratore and to Cicero's speeches, what we encounter is in fact a different instance of community building, still resting on puns and wittiness, but also relying on the exclusion of the victim. ${ }^{42}$

\section{2.b. The Mechanisms of Laughter}

The examples provided by De oratore show that joking also helps build a shared language and a shared understanding of the world. The treatise gathers many jokes based on quotations or allusions to well-known comic plays, and uses the trial of M. Duronius (97 BCE) as a telling example. Duronius was accused by C. Coelius Caldus of exacting bribes out of him through his son. When the witness left the bench, Crassus quipped "See: the old man's been tapped for thirty minae," a verse from an unknown comedy that everyone recognized at the time, and that implied that Caldus' son had kept the money for himself. ${ }^{43}$ Caldus was depicted as a character in a comedy, and everything suddenly made sense. A simple comic pattern efficient enough to stir up laughter provided a cogent account of the whole story, and Crassus used laughter as a framing device. This is precisely how Cicero proceeds in his most famous speech, Pro Caelio (56 BCE), where Caelius is charged with attempted poisoning and murder. By using several comic patterns, the advocate depicts the whole case as a love affair, in which everyone is cast in roles directly taken from Menander or Terence. ${ }^{44}$

Beyond the plots of well-known comedies, there were patterns, themes, and common narrative structures that formed the basic material for a good Roman laugh: ridiculous names, physical deformity, sexual impropriety, strange behavior, or improper dressing. In a face-toface society such as Rome, so obsessed with conformity, the length of a man's toga, his gait, and his tone of voice were inexhaustible sources of criticism and therefore of laughter. Humor thus becomes a most efficient tool of social control. By laughing down what the orator-and

\footnotetext{
${ }^{42}$ This understanding might look akin to what contemporary approaches define as a "superiority account" of laughter (Atkinson 1993: 10-15; Morreall 2009: 4-9), where humor serves to reassert one's sense of superiority. But the superiority account views laughter as a practice that should "have no place in a well-ordered society, for it would undermine cooperation, tolerance, and self-control" (Morreall 20o9: 7), a view Cicero would obviously not share, even though Quintilian links laughter (risus) and derision (derisus) when discussing Cicero's account (Inst. 6.3.8-9, 11.1.22). On the link between laughter and insolence, see, in particular, Aristotle, Rhet. 1378b23-28 and 138gbi1-12. The superiority account is seen by Fortenbaugh 200o; Skinner 2004; and Fortenbaugh and Gutas 2011: 328,540 as a valid way of understanding the Peripatetic theory of laughter, but M. Walker, in this volume (Chapter 5, "Aristotle on Wittiness"), convincingly demonstrates that such an approach is too limited.

${ }^{43}$ De orat. II.257.

${ }^{44}$ See Geffcken 1973; Hughes 1997; Leigh 2004.
} 
the community—sees as "dishonorable" and "ugly," humor both helps to define social norms and to enforce them..$^{45}$ In this new configuration, witticisms and laughs are not only shared and exchanged to sustain a relationship. They are also used to shape it in a particular way, by helping the audience see and understand something that had escaped their attention until then. ${ }^{46}$

Caesar Strabo implies that a joke must give the audience an occasion to understand, or even learn, something new, and force them to change their views according to this discovery. The case of Helvius Mancia, who was accusing one of Caesar Strabo's clients, offers a good illustration of the process:

"I said to Helvius Mancia: "Now I'll show everyone what you are like." When he replied "go ahead," I pointed at the picture of a Gaul on one of the Gallic shields captured in Marius' famous battle, which was hanging next to the New Shops: a distorted figure, with tongue sticking out and flabby cheeks. People laughed, for this looked more like Mancia than anything." (De orat. II.266)

This comic device is defined as an imago by Cicero, a joke based on resemblance. It is of course doubtful that Mancia would have looked like the painted apotropaic figure of the Gaul: what Strabo does, by joking in such a way, is remind everyone that Mancia-who was the son of a freedman - is inferior from a civic and social point of view. ${ }^{47}$

Caesar Strabo does not explain any further the mechanism at play here, but his joke obviously exploits the learning, or mathesis, function of witticisms and vivid metaphors that Aristotle underlined in his Rhetoric. According to Aristotle, we find a witticism-or a metaphor-pleasant if it surprises us, ${ }^{48}$ and if it makes us discover something that had previously escaped our attention. We thus make new associations, thanks to the vividness and relevance of the jester's remark: witticisms, just like metaphors, teach us something new. ${ }^{49}$ It is no wonder that, in De oratore, jokes depending on content—as opposed to wordplays ${ }^{5 \circ}$ -

\footnotetext{
${ }^{45}$ On this Roman "laughter of control," Corbeill 1996 offers the best account available. See also Richlin 1983; Guérin 2011: 159-66; Beard 2014: 99-127.

${ }^{46}$ The goal of the orator, as Corbeill 1996: $43-55$ clearly demonstrates, is to teach his audience how to read the world surrounding them according to his own agenda.

${ }^{47}$ David 1992: 9, Corbeill 1996: 40, Dufallo 2001: 137, Guérin 2011: 162 sq. On Mancia, see Steel 2013.

${ }^{48}$ Surprise is an essential component of funny witticisms (asteia), which must be deceptive and go against expectations (Rhet. 1412a27-31): see Chapter 2 (“Aristotle on Why We Laugh at Jokes"), §2, in this volume.

${ }^{49}$ See Rhet. 141ob12-36, 1412a19-22. Aristotle's approach is based on his understanding of metaphors and mimēsis as means for discovering new relations and significations and, ultimately, for learning. Cf. Rhet. 1371b8-10 (on mimèsis and works of art): "for the pleasure does not consist in the object portrayed; rather there is a reasoning that 'this' is 'that,' so one learns what is involved." See also Poet. 1448b12-17.

${ }^{5}$ On this division see De orat. II.239, $25^{2}$.
} 
always reveal something unexpected or previously unnoticed about their object. ${ }^{51}$ Laughter is the mechanical effect of the discovery facilitated by the joke.

Theophrastus' analysis of comic aggression (skōmma) provides another interpretation of the process. According to Theophrastus,

[a] gibe is a reproach for some fault, hidden under a figure; thus the hearer uses the allusion to supply the missing part, as if he knew the thing beforehand and believed it. ${ }^{2}$ (Quaest. conv. 2.1.4, 631 F)

Here, a gibe works well when the audience goes along with it and supplies what the jester leaves unsaid. It does not actually frame their views; it makes them all the clearer. Everybody knew that Mancia was an outsider, and the joke makes sense only because the public shares this knowledge and draws the right conclusions. ${ }^{53}$

Both Aristotle's and Theophrastus' approaches enrich Caesar Strabo's analysis, and both describe laughter as a process that creates an understanding between the jester and his public. By using patterns the public can quickly grasp, laughter makes the jester an insider, it builds a community of shared values based on the inclusion of himself and everyone around, and it depends on the exclusion of those whose flaws are now perfectly clear and spelled out. The jester still aims to enhance human relationships, but the circle of human societas is now reduced and excludes those whose "dishonorableness and ugliness" have been detected and pointed out..$^{4}$

When used in an oratorical context, laughter loses its gentleness and lightheartedness. Whereas sermo, in its ideal form, means that nothing is at stake except the pleasure and charm of the exchange, public speeches can never be reduced to a mere entertainment. The speaker aims at definite goals-persuading his public, winning an argument, or replying to an opponent - and uses jokes and laughter to achieve these. As a matter of fact, Cicero does not condone joking in a public setting unless the jokes have a clear purpose and help convince the audience:

We orators utter jokes for a specific reason, that is, not to seem funny, but to achieve something $\left[\ldots . .{ }^{55}\right.$ (De orat. II.247)

\footnotetext{
${ }^{51}$ De orat. II.243.

${ }^{52}$ My translation. Skōmma is already defined as a kind of insult by Aristotle (EN 1128a29-30), and Plutarch furthers the analysis of its effects (worse, in his views, than those of an insult). On the Peripatetic analysis of skōmmata, see Fortenbaugh 2006: 143-44.

${ }^{53}$ The mechanism is close to that of the enthymeme (Rhet. 140ob3o), which works only if it is understood right from beginning.

${ }^{54}$ De orat. II.236.

${ }^{55}$ On this requirement, which he sees as an "ethic of laughter," see Rabbie 1986: lxix-lxxiv.
} 
One could claim that laughter also proves useful in sermo when it creates cheerfulness. But it does so by itself, not by pursuing an external goal (ridiculing an opponent, excluding an outsider). In the realm of contentio, laughter has become instrumental and leaves no room for comitas. Even though laughter still seems to help create a community, the reversal seems almost complete.

\section{2.c. Public Image, Limits, and Restraint}

This use of aggressive laughter in the public sphere explains Cicero's interest in the jester's public image. Joking can of course have a very positive effect on the orator's ethos, since laughter helps him win the goodwill of the audience, and can do much good for his reputation:

It is indeed [...] clearly fitting for the orator to stir up laughter, [...] because cheerfulness (hilaritas) by itself wins goodwill for the one who has excited it, or because everyone admires cleverness (acumen) [...] or because it shows the orator himself to be refined (politus), educated (eruditus), and sophisticated (urbanus). (De orat. II.236)

All characters in De oratore agree that wittiness is a natural ability. It is not possible to impart the capacity to joke through theory or teaching, says Caesar Strabo, and everyone can see that a good pun has to be made on the spot, not prepared in advance. Laughter depends on the jester's ingenium, and a laughing crowd is in some way a tribute to the orator's intelligence. ${ }^{56}$ Joking certainly helps assert one's sense of superiority. But the preceding passage shows that this sense of superiority is also imparted by the orator's social and cultural skills, since joking helps him prove himself to be "refined," "educated," and "sophisticated." These social qualities all depend on the literary and artistic culture the orator will showcase through his puns and funny stories. ${ }^{57}$ But in Cicero's mind, they should also give him the ability to avoid any impropriety and to control himself while joking.

Joking always involves a risk. In the context of sermo, laughter may endanger the friendliness and closeness that bond human beings together, if it goes too far and becomes aggressive. The contentio implied by oratory, on the other hand, means that aggression is allowed whenever it can help the cause (as Roman forensic ethics imply that an advocate shall do everything to help his client), as long as it does not prove degrading (turpiter) for the jester himself or detract from his authority (gravitas). ${ }^{8}$ Restraint and self-control are of prime importance here and Cicero emphasizes the need to preserve one's image while joking.

\footnotetext{
${ }^{56}$ De orat. II.219-220; see Guérin 2011: 174-87. On the absence of an art of joking, see De orat. II.217-18, 247. For Aristotle (Rhet. 1410b6-8) as well, witticisms and refinements (asteia) depend on natural talent and on practice and cannot be taught (although their workings can be explained).

${ }^{57}$ On these three characteristics, see Guérin 2011: 192-265.

${ }^{58}$ De orat. II.229, 236; David 1992: 49-119
} 
De oratore thus develops a social interpretation of laughter that seems to take a clearly Peripatetic view of the phenomenon. ${ }^{59}$ Aristotle's Nicomachean Ethics reflect on how to joke properly: shall we define the good jester as one "who says what is not inappropriate for a liberal human being," or as one "who does not cause pain to the listener (but instead causes him delight)" (EN IV.8.1128a25-27)? Aristotle dismisses the second criterion as unsuitable, since one cannot predict what people will like or dislike, ${ }^{6 \circ}$ and he suggests that social acceptability is the only efficient norm in this case. The good jester, tactful and witty (epidexios and eutrapelos:1128a33), will personify this norm. In the same way, Cicero leaves aside any consideration for the feelings of others, and focuses on the jester as an incarnation of good taste and moderation.

Cicero's goal is to define the limits within which one can joke appropriately. The orator shall refrain from joking if the joke does not help his client or cause (laughter being once again instrumental) or if it exceeds the boundaries of good taste, for fear of jeopardizing his own status. ${ }^{61}$ Efficiency is the paramount criterion here, as one could expect. The orator shall also use consideration and not turn great crimes into jokes: it would be inefficient, and, in these cases, stirring up emotions works much better. He must not antagonize the public either by making fun of misery or by ridiculing someone popular. ${ }^{62}$ But above all, he must exert restraint (moderatio) and not joke at an unsuitable time or at all costs, unless he wants to be ridiculed himself and ruin his standing. The orator L. Marcius Philippus once joked on the small size of a witness in front of a judge who wanted him to proceed quickly: "Don't worry," Philippus quipped, "I'll question him just a tiny bit." But one of the jurors happened to be even smaller than the witness, and "all laughter was directed toward the juror" (De orat. II.245). For sure, the joke was funny (ridiculus), but that does not mean it was also witty (facetus). By joking at the wrong time and in front of the wrong person, Philippus alienated the jury and endangered his case: he indulged in buffoonery (scurrile ridiculum) and forgot his duties as an orator. ${ }^{63}$

Here again, the Peripatetic influence is obvious, and Cicero's reflection seems to take up Aristotle's insistence on the difference between a kind of laughter that is suitable for the liberal man (eleutherios), and another one belonging to the buffoon (bómolochos). ${ }^{64}$ The Aristotelian good jester we just encountered is defined as a middle term between the excessive laughter characteristic of buffoonery (bömolochia), and the complete lack of humor

\footnotetext{
${ }^{59}$ On the Peripatetic influence on Cicero's understanding of laughter, see Grant 1924: 73 sq.; Leeman, Pinkster, and Rabbie 1989: 191-93; Corbeill 1996: 21-22; Beard 2014: 110.

${ }^{60}$ Plutarch (Conv. 2.1.9) explains that, in order not to hurt anyone with a joke, one must take everyone's nature into account and adapt to it.

${ }^{61}$ De orat. II.237, 245, 247.

${ }^{62}$ De orat. II.237.

${ }^{63}$ De orat. II.245, 251.

${ }^{64} \mathrm{EN} \mathrm{1128 \textrm {a } 4 - 1 7 .}$
} 
characteristic of boorishness (agroikia). The buffoon does not control himself and jokes as often as he can with no concern for the requirements of good taste. On the other hand, the eutrapelos always stays in control and cares only for jokes worthy of a free man. ${ }^{65}$ Cicero, who is not interested in building a theory of the virtuous middle term, completely leaves aside the boor in his musings, but he makes full use of the counter-model of excessive laughter.

When he outlines the limits of proper joking, Cicero uses two examples of excess: the buffoon (scurra) and the mime (sannio, mimus, ethologus). Both are socially degraded and illustrate a corrupt version of the two correct comic practices, jest (dicacitas) and funny anecdotes (cauillatio). ${ }^{6}$ The scurra jokes without any consideration for his audience (petulantia) or the circumstances (intempestiuitas), and without any regard for his own dignity: he simply cannot refrain from joking. ${ }^{67}$ The mime, in line with his theatrical model, is obscene and makes himself the object of laughter by using antics and comic caricatures. ${ }^{68}$ They both illustrate the excessive use of laughter that the orator must avoid at any cost for fear of looking like a social inferior and of proving unable to refrain his impulses. By joking at the wrong time, on the wrong topic, or in the wrong way (as Philippus did), the orator might ruin his own authority and, along with it, the very sense of community he was trying to convey.

Contentio has replaced the ethics of friendliness by concerns for one's image. Rhetoric thus redefines what counts as an improper joke: not one that might hurt the victim's feelings, but one that is not in accordance with the general expectations of the public. The Ciceronian good jester seems of course very close to the Aristotelian eutrapelos and his tactful use of laughter, but as a rhetorical and political treatise, De oratore limits its approach to the selffashioning of the orator. It does not tackle the relation between laughter and the jester's character, an issue that reemerges in Cicero's De officiis, where the respect of social norms is put at the core of the moral agent's persona.

\section{The Jesting Persona: An Ethic of Laughter}

In the first book of De officiis, Cicero gives a philosophical twist to the notion he used as a cornerstone of his rhetorical doctrine two years before in Orator (46 BCE), that of decorum ("propriety"), which translates the Greek notion of prēpon. The term decorum-which is entirely absent from De oratore - is in fact coined by Cicero to replace various rhetorical notions linked to the proper choice of ideas or words, and to oratorical action. ${ }^{69}$ Cicero's Orator innovates by stressing the link between decorum in speaking and in life, and calls

\footnotetext{
${ }^{65}$ Rhet. 1419b 7-10; EN 1108a23-26, 28-32, 34-35. See Fortenbaugh 200o; Jaulin 200o; Halliwell 2008: 317-19; and Chapter 5 ("Aristotle on Wittiness"), in this volume.

${ }^{66}$ Guérin 2011: 265-303.

${ }^{67}$ See De orat. II.247 and Guérin 2011: 273-88.

${ }^{68}$ De orat. II.239, 242, 251-52.

${ }^{69}$ Cicu 200o: 139.
} 
openly for a philosophical treatment of the concept instead of a rhetorical one: decorum thus becomes a guiding principle for speaking, behavior, and actions, both in public and private settings. ${ }^{70}$ In fact, the more Cicero uses the concept, the more it expands. In 44 BCE, De officiis will try to give decorum its full scope by linking it to the Stoic tradition, and, in particular, to the ethical prepon devised by Panaetius.

Cicero's theory of duties divides the honorable (honestum) into four parts: the perception of truth, the conservation of society and the upholding of contracts, greatness of spirit and, last, order and moderation. ${ }^{71}$ The last division corresponds to the ethical decorum that Cicero analyzes in Off. I.93-151. Following Panaetius, Cicero makes the decorum one of the four cardinal virtues, and the principle of propriety thus becomes a cornerstone of one's ethical life. To maintain decorum, the moral agent must, first, be adequate to human excellence (decorum generale), and, second (decorum subjectum), seek this propriety by showing moderation (moderatio), control over his emotions (temperentia), and a behavior characteristic of a free man (liberalitas). Cicero then takes two examples from Accius' play Atreus to explain that decorum is maintained when a man's actions and speeches are in accord with his character (persona, Off. I.97). Decorum thus turns into a general principle of appropriateness between an agent and his actions. ${ }^{72}$ Being appropriate to oneself becomes a virtue to be protected at all costs, and De officiis develops what can be characterized as a particularist ethic, in which an agent's character plays "a prominent role in the determination of what counts as right or wrong action." ${ }^{73}$

Decorum subjectum goes beyond this general principle of balance between agent and action, and gives it a definite content, which is socially determined. This definition might stem from Panaetius or entirely from Cicero. In any case, Cicero endorses the view and suggests that nature should not be the only principle governing decorum, but that decorum also needs to rest on a social standard. This principle and its social basis bring Cicero back to laughter.

After defining the decorum principle, Cicero outlines the various duties deriving from it. Decorum calls for seriousness, which itself consists in rational control over one's impulses (constantia and moderatio, Off. I.102). The moral agent must avoid showing his passions (whether joy or anger) or doing anything without due consideration. He must also avoid any infringement of social norms, and joking is no exception. But as we have seen, De officiis does not forbid laughter and jest. It comes as a perfectly legitimate activity when serious matters have already been dealt with, and it contributes to harmonious human relationships. Nevertheless, respecting decorum means that the jester has to abide by a few essential rules, and De officiis divides laughter into two opposite kinds that translate the categories used in De

\footnotetext{
${ }^{70}$ Orat. $72-74$. See Guérin 2oogb.

${ }^{71}$ Off. I.15. On the relationship between these elements, see Dyck 1996: 100.

${ }^{72}$ Goldschmidt 2006: 127 .

${ }^{73}$ Woolf 2007: $3^{21 .}$
} 
oratore, turning them into properly ethical norms. These two kinds of laughter are opposed to each other according to the social qualities or flaws they imply in the jester:

There are, generally speaking, two sorts of jest: the one unworthy of a free man (illiberale), insolent (petulans), outrageous (flagitiosum), indecent (obscenum); the other, refined (elegans), sophisticated (urbanum), clever (ingeniosum), witty (facetum). (Off. I.104)

Cicero then sums up his argument by contrasting an ingenuus and an illiberalis jocus:

It is easy to make the distinction between a well-bred joke (ingenuus jocus) and one unworthy of a free man (illiberalis jocus), the former, provided the time is right, as when one is relaxing, is worthy of even the <most serious $>$ man; the latter, if one uses indecent words (obscenitas) to treat a dishonorable subject (turpitudo), is unworthy of any free man. (Off. I.104)

Applied to laughter, this principle of ethical propriety feels a lot like a mere respect for social order and good taste. ${ }^{74}$ It also seems quite similar to Cicero's approach in De oratore. We can easily go beyond that first impression, however, and further explain this last stage of Cicero's analysis of laughter.

Although proper joking seems to follow the rules already defined by Cicero in the context of oratory (timely, not endangering one's gravitas, rejecting vulgarity), it is now linked to the characteristics of the freeborn man (ingenuitas and liberalitas) that were never explicitly used in De oratore. ${ }^{75}$ Instead of describing how to joke by using negative examples (scurra and mimus), Cicero now defines the good jester as someone who embodies the respect for social norms. The similarity to the Aristotelian eutrapelos-whose tact is characteristic of the free man, and whose way of having fun greatly differs from that of the slave-is now even greater, and the point of view seems to have changed radically. Whereas Cicero was concerned only with the orator's image in De oratore, he is now, and for the first time, interested in the jester's character - not as a disposition making one prone to witticisms or to vulgar puns, but as something that laughter can affect, in a way that recalls Plato's concerns.

The main challenge of laughter, for Cicero, does not only lie in its potential for excess and irrationality (even though his fears in this regard are clearly stated in Off. I.104, as we have seen); it might also threaten the coherence of the self, a coherence on which the maintaining of decorum, and thus the upholding of duties, directly depends. This combination of arguments centered on sociability (Off. I.134 sq.) and social norms (Off. I.103-4) with a concern for the self should not come as a surprise. The doctrine of decorum is precisely meant to close the gap between social and ethical norms, as well as between civic community and individual

\footnotetext{
${ }^{74}$ The rejection of obscenity is also linked to the controversy between Stoics and Academicians on the use of obscene words: see Off. I.128; Fam. 9.22; Romeyer-Dherbey 1990.

${ }^{75}$ De orat. uses the adjective liberalis only once, to characterize excessive imitation as non liberale (II.253).
} 
self. And it is to further the understanding of decorum and insist even more on the centrality of human societas to ethical life that Cicero takes up Panaetius' well-known four-personae theory. ${ }^{76}$

According to Off. I.1O7-21, every human being has been given four personae that form not a "purely theoretical or analytic framework for the understanding of the person," but "key normative reference-points in rational, moral choice." ${ }^{77}$ The first two personae are given by nature: the agent's human nature endowed with reason, and his own individual dispositions. The two others are added to these "natural" elements, the third persona stemming from the agent's social standing, the fourth one from the course of life he has chosen, which is partly conditioned by the three other personae and depends on one's personal aspirations.

These reference points build what Carlos Lévy calls "a pedagogical casuistry," ${ }^{8}$ an ethical tool that the moral agent can use to assess his choices and ponder if they are adequate to his personae. The validity of an action thus depends not only on respecting the fundamental principles of justice, but also on being true to oneself. ${ }^{79}$ This principle explains why Cato's suicide is laudable: "since nature had assigned to Cato an extraordinary seriousness" that he "had consolidated by the unfailing constancy" he had chosen as a course of life, "he had to die rather than look upon the face of a tyrant." Had his companions done the same thing, "it would perhaps have been counted as a fault, for the very reason that they had been more gentle in their lives, and more easy-going in their behavior" (Off. I.112).

Not all examples chosen by Cicero are as tragic as this one, and when he defines the second persona (individual dispositions), he contrasts those who display charm (lepos: L. Crassus, L. Philippus) with those endowed with more seriousness (severitas: M. Scaurus, M. Drusus), those who are cheerful (hilaritas: C. Laelius) and those who show more earnestness (vita tristior: Scipio, Off. I.108). Some, in other words, are prone to laughter and others less, and it would be easy to conclude that the witty ones might have to display their wit in order to stay true to themselves. But Cicero then adds a caveat:

Each person should hold on to what is his as far as it is not vicious, but is peculiar to him, so that the propriety that we are seeking might more easily be maintained. ${ }^{80}$ (Off. I.110)

Does vice (vitium) bring us back to the more general principles of justice or honorableness, and force us to leave aside the particularist ethic and methodology the four-personae theory

\footnotetext{
${ }^{76}$ De Lacy 1977; Gill 1988; Lévy 2003; Reydams-Schils 2005: 27-28 and 93 sq.; Forschner 2005.

${ }^{77}$ Gill 1988: 176.

${ }^{78}$ Lévy 2003: 136.

${ }^{79}$ Woolf 2007: 337 .

${ }^{80}$ Brutus, the history of Roman eloquence Cicero wrote in $46 \mathrm{BCE}$, lists wittiness among the relevant characteristics of the orators under scrutiny. L. Licinius Crassus (Brut. 197 sq.) is already used as an example there, along with Caesar Strabo (Brut. 177, 216).
} 
seems to build? Not necessarily, since the third and fourth personae-social standing and choice of life-do offer other normative references to use. In the case of laughter, the wellborn individual who has chosen the path of honorability should favor the well-bred kind of jokes, and control his jesting at all times. In other words, the characteristics of the second persona have to be regulated by the requirements of the other ones. Respecting decorum means adhering to all four personae at the same time, and social standing is as much a part of a man's identity as his emotional character. And in light of the general orientation of the treatise and its concern for civic community, the third and fourth personae might even "take precedence over other normative reference points." ${ }^{81}$ Above all, a behavior is deemed adequate when it fits with a man's status (that is, when he keeps in mind that he is a member of the elite), and every action becomes an occasion to renew and reinforce this coherence between the agent and his deeds. This standard is why the mainly social approach to laughter we find everywhere in Cicero is not at odds with the ethics he builds in De officiis. In his views, social norms are at the core of an agent's persona and, as G. Reydams-Schils points out, the "philosophical norm of a rational human nature" becomes fused with the "construct of social values." $^{82}$

\section{Conclusion}

From his first comprehensive analysis in De oratore to his last reflections in De officiis, Cicero's understanding of laughter seems to take very different shapes. Four strands can be identified in his works. First, laughter appears as a means for protecting and even enhancing human relationships, mostly in a private setting. In the public sphere, Cicero sees laughter as a tool used to enforce social norms by aggressively excluding deviants and strengthening the bonds of the community. The question of self-control thus plays a central role in Cicero's De oratore, since joking and laughing have a strong impact on the jester's image, either enhancing or ruining it. Lastly, in De officiis, Cicero's thought takes an ethical turn to tackle the effect of laughter on the jester's self, and social norms are placed at the core of the moral agent's persona.

Since the norms that regulate the jester's behavior are the very same ones that help him maintain his own appropriateness and ethical coherence in De officiis, there can be no gap between the jester's image and his actual ethical self, or any contradiction between his individual aspirations and the requirements of his social standing. If a bad joke can shatter the jester's image in front of the public because it is not liberalis, it also puts his real self at stake by compromising his ethical stability. The jester is always what he seems to be and, in the end, there is no real difference between Cicero's rhetorical and ethical approach to laughter.

\footnotetext{
${ }^{81}$ Reydams-Schils 2005: 94. See Gill 1988: 170-71.

${ }^{82}$ Reydams-Schils 2005: 94.
} 
From 55 to 44 BCE, the coherence of Cicero's analysis stems from the fact that laughter, in his views, illustrates perfectly what's at stake in the relationship between the moral agent and the community he belongs to. Cicero never sets jokes, puns, and funny stories in a separate space where the free spirit of banter would rule without any regard for the usual workings of human relationships or the requirements of civic duties. Whatever the approach Cicero chooses, he always views laughter as a tool used to enhance the cohesion and strength of the community. When used properly, laughing and joking are not rebellious acts, and even if joking helps showcase the jester's culture and wit, it should never be disruptive and should never hurt the public's expectations. The jester Cicero has in mind is not an outsider or a critic of the social order, and laughter is never seen as a moral threat deserving a global condemnation. Quite the contrary, the accomplished jester, whom Cicero fancied himself to be, makes a useful contribution to the general welfare of the State, and embodies somehow a lighthearted version of the perfect citizen, whose behavior always abides by the norms of the community. Those are the very same norms, of course, which his enemies accused Cicero of infringing by the jokes he made. ${ }^{83}$

\section{Bibliography}

Atkins, E. M., and Griffin. M. T. (1991), Cicero: “On Duties," Cambridge: Cambridge University Press.

Atkinson, R. F. (1993), "Humour in Philosophy," in K. Cameron (ed.), Humour and History, Oxford: Intellect Books, 10-2O.

Auvray-Assayas, C. (1998), "Le rire des Académiciens: la citation comique dans le De natura deorum de Cicéron", in C. Auvray-Assayas and P. Hoffmann (ed)., Le Rire des anciens, Paris: Éditions rue d'Ulm, 293-306.

Bartlett, R. C., and Collins, S. D. (2011), Aristotle's “Nicomachean Ethics," Chicago: University of Chicago Press.

Beard, M. (2014), Laughter in Ancient Rome: On Joking, Tickling and Cracking Up, Berkeley: University of California Press.

Bernard, J.-E. (2013), La sociabilité épistolaire chez Cicéron, Paris: Honoré Champion.

Celentano, M. S. (1995), "Comicità, umorismo e arte oratoria nella teoria retorica antica," Eikasmos 6: 161-74.

Cicu, L. (2000), “Cicerone e il prepon,” Paideia 55: 123-62.

Connolly, J. (2007), The State of Speech: Rhetoric and Political Thought in Ancient Rome, Princeton, NJ: Princeton University Press.

\footnotetext{
${ }^{83}$ Dugan 2005: 107-11; Beard 2014: 100-105.
} 
Corbeill, A. (1996), Controlling Laughter: Political Humor in the Late Roman Republic, Princeton, NJ: Princeton University Press.

Craig, C. (1986), "Cato's Stoicism and the Understanding of Cicero's Speech Pro Murena," TAPhA 116: 229-39.

David, J. M. (1992), "Compétence sociale et compétence oratoire à la fin de la République: Apprendre à ressembler," in E. Frézouls (ed.), La mobilité sociale dans le monde romain: Actes du colloque de Strasbourg (novembre 1988 s), Strasbourg: AECR, 7-19.

Desclos, M. L., ed. (2000), Le rire des Grecs: Anthropologie du rire en Grèce ancienne, Grenoble, France: Jérôme Millon.

De Lacy, P. (1977), "The Four Stoic Personae," Illinois Classical Studies 2: 163-72.

Dufallo, B. (2001), "Appius' Indignation: Gossip, Tradition, and Performance in Republican Rome," TAPhA 131: 119-42.

Dugan, J. (2005), Making a New Man: Ciceronian Self-Fashioning in the Rhetorical Works, Oxford: Oxford University Press.

Dyck, A. R. (1996), A Commentary on Cicero: "De officiis," Ann Arbor: University of Michigan Press.

Fantham, E. (2004), The Roman World of Cicero's “De oratore," Oxford: Oxford University Press.

Forschner, M. (2005), "Le portique et le concept de personne," in G. Romeyer Dherbey and J. B. Gourinat (eds.), Les Stoïciens, Paris: Vrin, 293-317.

Fortenbaugh, W. (2000), “Une analyse du rire chez Aristote et Théophraste," in Desclos, 33354 .

Fortenbaugh, W., and Gutas, D., eds. (2011), Theophrastus of Eresus: Sources for His Life, Writings, Thought and Influence. Commentary Volume 6.1, Sources on Ethics, Leiden, The Netherlands: Brill.

Fortenbaugh, W. W. (2006), Aristotle's Practical Side: On His Psychology, Ethics, Politics and Rhetoric, Leiden, The Netherlands: Brill.

Geffcken, K. A. (1973), Comedy in the "Pro Caelio," Leiden, The Netherlands: Brill.

Gill, C. (1988), "Personhood and Personality: The Four-Personae Theory in Cicero, De officiis I," Oxford Studies in Ancient Philosophy 6: 169-99.

Goldschmidt, V. $\left(2006^{3}\right)$, Le système stoïcien et l'idée de temps, Paris: Vrin.

Grant, M. A. (1924), The Ancient Rhetorical Theories of the Laughable: The Greek Rhetoricians and Cicero, Madison: University of Wisconsin Press.

Guérin, C. (20oga), Persona: L'élaboration d'une notion rhétorique au $I^{\text {er }}$ siècle av. J.-C. Vol. I: Antécédents grecs et première rhétorique latine, Paris: Vrin. 
Guérin, C. (2009b), "Philosophical Decorum and the Literarization of Rhetoric in Cicero's Orator," in F. Woerther (ed.), Literary and Philosophical Rhetoric in the Greek, Roman, Syriac and Arabic World, Hildesheim, Germany: Olms, 119-39.

Guérin, C. (2011), Persona: L'élaboration d'une notion rhétorique au I'r siècle av. J.-C. Vol. II: Théorisation cicéronienne de la persona oratoire, Paris: Vrin.

Halliwell, S. (2008), Greek Laughter: A Study of Cultural Psychology from Homer to Early Christianity, Cambridge: Cambridge University Press.

Hughes, J. J. (1997), “Inter Tribunal et Scaenam: Comedy and Rhetoric in Rome," in W. J. Dominik (ed.), Roman Eloquence: Rhetoric in Society and Literature, London: Routledge, $182-97$.

Hutchinson, G. O. (1998), Cicero's Correspondence: A Literary Study, Oxford: Clarendon Press.

Jaulin, A. (2000), "Le rire logique: Usages de geloion chez Aristote," in Desclos (2000), 319-32.

Kennedy G. A. (2007), Aristotle- “On Rhetoric”: A Theory of Civic Discourse, Oxford: Oxford University Press.

Kennerly M. (2010), “Sermo and Stoic Sociality in Cicero's De Officiis”, Rhetorica 28: 119-37.

Krostenko, B. (2001), Cicero, Catullus and the Language of Social Performance, Chicago: University of Chicago Press.

Leeman, A. D., Pinkster, H., and Rabbie, E. (1989), M. Tullius Cicero "De oratore" libri III, Kommentar, 3. Band: Buch II, 99-29o, Heidelberg: Carl Winter Universitätsverlag.

Le Goff, J. (1989), "Rire au Moyen Âge," Cahiers du centre de recherches historiques 3: 1-14.

Leigh, M. (2004), "The Pro Caelio and Comedy," Classical Philology 99: 300-35.

Lévy, C. (1989), “Le De officiis dans l'œuvre philosophique de Cicéron,” Vita Latina 116:11-6.

Lévy, C. (1992), Cicero academicus: Recherches sur les Académiques et sur la philosophie cicéronienne, Rome: École française de Rome.

Lévy, C. (1993), "La conversation à Rome à la fin de la République: Des pratiques sans théorie?," Rhetorica 11: 399-420.

Lévy, C. (1995), "Le mythe de la naissance de la civilisation chez Cicéron," in S. Cerasuolo (ed.), Mathesis e philia: Studi in onore di Marcello Gigante, Naples, Italy: Università degli Studi di Napoli, $155^{-68 .}$

Lévy, C. (2003), "Y a-t-il quelqu'un derrière le masque?," Ítaca. Quaderns Catalans de Cultura Clàssica 19: 127-40.

May J., and Wisse, J. (2001), Cicero, “On the Ideal Orator," Oxford: Oxford University Press.

Morreall, J. (2009), Comic Relief: A Comprehensive Philosophy of Humor, Malden, MA: WileyBlackwell. 
Prost, F. (2001), "La psychologie de Panétius: Réflexions sur l'évolution du stoïcisme à Rome et la valeur du témoignage de Cicéron," Revue des études latines 79: 37-53.

Rabbie, E. (1986), Cicero über den Witz: Kommentar zu "De oratore" II, 216-29o, PhD diss., Amsterdam.

Reydams-Schils, G. J. (2005), The Roman Stoics: Self, Responsibility, and Affection, Chicago: University of Chicago Press.

Richlin, A. (1983), The Garden of Priapus: Sexuality and Aggression in Roman Humor, New Haven, CT: Yale University Press.

Romeyer Dherbey, G. R. (1990), "Zénon appelle les choses par leur nom: La chasteté de la langue d'après les stoïciens," Mesure 3: 47-59.

Shackleton Bailey D. R. (1999), Cicero, "Letters to Atticus," Harvard: Harvard University Press.

Shackleton Bailey D. R. (2001), Cicero, "Letters to Friends," Harvard: Harvard University Press.

Schofield, M. (1999), The Stoic Idea of the City, Chicago: University of Chicago Press.

Skinner, Q. (2004), Visions of Politics 3: Hobbes and Civil Science, Cambridge: Cambridge University Press.

Steel, C. (2013), "Pompeius, Helvius Mancia, and the Politics of Public Debate," in C. Steel and H. Van der Blom, Community and Communication. Oratory and Politics in Republican Rome, Oxford: Oxford University Press, 151-59.

White, P. (2010), Cicero in Letters: Epistolary Relations in the Late Republic, Oxford: Oxford University Press.

Woolf, R. (2007), "Particularism, Promises, and Persons in Cicero's De officiis," Oxford Studies in Ancient Philosophy 33: 317-46. 